\title{
Application of the Multi Criteria Decision Making Methods for Project Selection
}

\author{
Prapawan Pangsri \\ Faculty of Industrial Technology, Valaya Alongkorn Rajabhat University under the Royal Patronage, Thailand \\ *Corresponding Author: prapawan.pangsri@gmail.com
}

Copyright (C) 2015 Horizon Research Publishing All rights reserved.

\begin{abstract}
Multi-criteria decision making (MCDM) methods are chosen among alternatives in order to attain specific objectives. In this research, the purpose of methodology is to provide decision methods for project managers in construction companies. The methodology is combined into three methods consisting of Delphi method, Analytic Hierarchy Process (AHP) and Technique for Order Preference by Similarity to Ideal Solution (TOPSIS). As the result, the criteria for selection are determined by expert opinions, and then assign the weight of criteria by AHP. Finally, TOPSIS method is used to evaluate alternatives which are found prioritized by weight for project, namely project 5 equal 0.747 , project 7 equal 0.746 , project 3 equal 0.614 , project 2 equal 0.441 , project 4 equal 0.386 , project 1 equal 0.358 and project 6 equal 0.264 respectively.
\end{abstract}

Keywords Multi-criteria Decision Making, AHP, TOPSIS, Project Selection

\section{Introduction}

All organizations have to select the projects which are determined to pursue among numerous opportunities. One of the biggest decisions that any organizations are likely to make related to the projects which they would undertake. Once a proposal has been accepted, there are numerous factors that need to be considered before an organization decides to carry out. Actually, there are various project selection methods practiced by the modern business organizations. However, the most popular one is a multi-criteria decision making (MCDM) method which is a tool aimed at supporting decision makers who are faced with making numerous and conflicting evaluations. MCDM aims at highlighting those conflicts and deriving a way to come up with a compromise in a transparent process. Many researchers have studied about tools used in decision-making process to ensure the most appropriate alternative. Meanwhile, they applied the multi-criteria decision making for supporting any decision information process such as Affinity Diagram, Analytic Hierarchy Process (AHP), fuzzy TOPSIS, Analytic Network Process (ANP) and Technique for Order Preference by Similarity to Ideal Solution (TOPSIS) etc[1].

Many researchers have applied these methods into many organizations and several fields for instance project selection, project performance, logistics and computer system, etc. Anjali Awasthi and Satyaveer S Chauhan (2012) [1] combined three methods including Affinity Diagram, AHP and fuzzy TOPSIS for improving city sustainability by evaluating 4 city logistics initiatives. For project selection, Pablo et.al (2014) [2] applied AHP and ANP to help manager to decide project investment. Nikzad Manteghi et.al (2012) [3] used AHP method to select project suitable for distributed generation technology between current and new project. Nooshin Rahmania (2012) [4] applied AHP in IT project selection.Mohammed I. Al Khalil (2012) [5] developed AHP to select the most appropriate project delivery method.Morteza Pakdin Amiri (2012) [6] applied AHP to select oil field project. Doraid Dalalah et.al (2010) [7] applied AHP in construction project Chun-Chin Wei (2005) [8] applied in ERP project. Norita Ahmad and Phillip A. Laplante (2006) and Kamal M. Al-Subhi Al-Harbi (2001) $[9,10]$ applied to select software project. Evangelos Triantaphyllou and Stuart H. Mann (1995) applied to select computer system in engineering department. All research is presented in table 1 .

The most famous tool of the multi-criteria decision making methods is the Analytic Hierarchy Process (AHP) which is a methodology for supporting complex decisions. It is used in business and governmental sectors around the world to improve the quality of decisions. It is very intuitive, easy to use and understandable. While the Technique for Order Preference by Similarity to Ideal Solution (TOPSIS) is a multiple criteria decision making method based on the idea that the optimal solution should have the shortest distance from the positive ideal solution and the farthest distance from the negative ideal solution. So those methods will be applied in this research. 
Table 1. Literature review

\begin{tabular}{|c|c|c|c|c|c|}
\hline \multirow[b]{2}{*}{ Reference } & \multirow[b]{2}{*}{ Method } & \multicolumn{4}{|c|}{ Research area } \\
\hline & & $\begin{array}{l}\text { logistics } \\
\text { planning }\end{array}$ & Select projects & Project performance & Computer system \\
\hline [1] & $\begin{array}{l}\text { Affinity Diagram, } \\
\text { AHP and fuzzy } \\
\text { TOPSIS }\end{array}$ & * & & & \\
\hline [2] & $\begin{array}{l}\text { AHP, } \\
\text { ANP }\end{array}$ & & $*$ & & \\
\hline \multirow[b]{2}{*}{ Reference } & \multirow[b]{2}{*}{ Method } & \multicolumn{4}{|c|}{ Research area } \\
\hline & & $\begin{array}{l}\text { logistics } \\
\text { planning }\end{array}$ & Select projects & Project performance & Computer system \\
\hline [11] & AHP & & & $*$ & \\
\hline$[3],[4,5],[7],[8],[9],[10]$ & AHP & & $*$ & & \\
\hline$[6],[12]$ & AHP,fuzzy TOPSIS & & $*$ & & \\
\hline [13] & AHP & & & & $*$ \\
\hline [14] & Fuzzy & & $*$ & & \\
\hline$[15]$ & $\begin{array}{l}\text { Fuzzy AHP and } \\
\text { TOPSIS Technique }\end{array}$ & & $*$ & & \\
\hline
\end{tabular}

\section{Materials and Methods}

\subsection{The Delphi Method}

The Delphi method is an exercise in group communication. This technique allows experts to deal systematically with a complex problem or task. Amol A. Talankar et.al (2014) [16] had used Delphi method to identify the critical success factors (CSFs) for the effective implementation of Six Sigma in service sector. They collected all factors from literature to discuss with expert and finalize the set of critical success factors (CSFs). Othoman Elsayah et.al (2013) [17] ever applied delphi method to develop ranking contractor selection criteria with specific application to run construction projects in the Libyan context. Han-Gook Kim, Dong-Suk Hong (2012) [18] used Delphi method to develop the assessment tools for Green \& Smart IT level. Consequently, the part of expert opinions will be applied in this research to collect factors affecting to project selection.

\subsection{The Analytic Hierarchy Process (AHP)}

The Analytic Hierarchy Process (AHP) is a structured technique for dealing with complex decisions. It was developed by Thomas L. Saaty in the 1970s. AHP is designed to describe its three basic functions that feature complexity, measuring on a ratio scale, and synthesizing. The decision methods of AHP are as follow[19];

1. Define the problem and determine the goal of problem.

2. Determine the decision hierarchy from the top with the goal of the decision, then the objectives from a broad perspective, through the intermediate levels towards the lowest level.

3. Construct a set of pair wise comparison matrices. Each element in an upper level is used to compare the elements in the below level immediately with respect to it. Each of these judgments is assigned a number on a scale in table 2. Consider $n$ elements to be compared $C_{1} \ldots C_{n}$ and denote the relative 'weight' (priority or significance) of $C_{i}$ with respect to $C_{j}$ by $a_{i j}$ and form a square matrix $\mathrm{A}=\left(a_{i j}\right)$ of order $n$ with the constraints that $a_{i j}=1 / a_{j i}$, for $i \neq j$, and $a_{i i}=1$, all $i$.

4. Use the priorities obtained from the comparisons to weigh the priorities in the level immediately below. Do this for every element. Then for each element in the level below add its weighed values and obtain its overall or global priority. Continue this process of weighing and adding until the final priorities of the alternatives in the bottom most level are obtained.

Table 2. The Saaty rating scale

\begin{tabular}{|c|c|c|}
\hline $\begin{array}{c}\text { Intensity } \\
\text { of importance }\end{array}$ & Definition & Explanation \\
\hline 1 & $\begin{array}{c}\text { Equal } \\
\text { importance }\end{array}$ & $\begin{array}{l}\text { Two factors contribute } \\
\text { equally to the objective }\end{array}$ \\
\hline 3 & $\begin{array}{l}\text { Somewhat more } \\
\text { important }\end{array}$ & $\begin{array}{l}\text { Experience and judgment } \\
\text { slightly favor one over the } \\
\text { other. }\end{array}$ \\
\hline 5 & $\begin{array}{l}\text { Much more } \\
\text { important }\end{array}$ & $\begin{array}{c}\text { Experience and judgment } \\
\text { strongly favor one over the } \\
\text { other. }\end{array}$ \\
\hline 7 & $\begin{array}{l}\text { Very much more } \\
\text { important }\end{array}$ & $\begin{array}{l}\text { Experience and judgment } \\
\text { very strongly favor one over } \\
\text { the other. Its importance is } \\
\text { demonstrated in practice. }\end{array}$ \\
\hline 9 & $\begin{array}{l}\text { Absolutely more } \\
\text { important }\end{array}$ & $\begin{array}{l}\text { The evidence favoring one } \\
\text { over the other is of the } \\
\text { highest possible validity }\end{array}$ \\
\hline $\begin{array}{c}\text { Intensity } \\
\text { of importance }\end{array}$ & Definition & Explanation \\
\hline $2,4,6,8$ & $\begin{array}{l}\text { Intermediate } \\
\text { values }\end{array}$ & When compromise is needed \\
\hline
\end{tabular}


Table 3. Random Consistency index values for different values of $n$.

\begin{tabular}{|c|c|c|c|c|c|c|c|c|c|c|}
\hline $\mathrm{n}$ & 1 & 2 & 3 & 4 & 5 & 6 & 7 & 8 & 9 & 10 \\
\hline $\mathrm{CI}$ & 0.00 & 0.00 & 0.58 & 0.90 & 1.12 & 1.24 & 1.32 & 1.41 & 1.45 & 1.49 \\
\hline
\end{tabular}

5. Finally, a Consistency Index $(C I)$ can be calculated $\lambda_{\max }-n /(n-1)$. The consistency ratio CR is obtained by dividing the $\mathrm{CI}$ value by the Random Consistency index $(R C I)$ as given in table 3.

The process of assigned weight will apply by using this method.

\subsection{The Technique for Order Preference by Similarity to Ideal Solution (TOPSIS)}

The technique for order preference by similarity to ideal solution (TOPSIS) is a widely accepted multiple criteria method to identify solutions from a finite set of alternatives. A solution is determined as a positive ideal solution if it maximizes the benefit criteria or minimizes the cost criteria. On the other hand, the solution which maximizes the cost criteria or minimizes the benefit criteria is called the negative ideal solution. In the initial step of the technique, let $x_{i j}$ be the inputs for matrix of priorities where there are $i=1 \ldots, m$ alternatives and are $j=1 \ldots, n j$ criteria. Then Form normalized decision matrix, the positive ideal solution $\left(A^{+}\right)$is determined by selecting the largest normalized and weighted score for each criterion. Similarly, the negative ideal solution $\left(A^{-}\right)$is determined by selecting the least normalized and weighted score of each criterion[20]

$$
r_{i j}=\frac{x_{i j}}{\sqrt{\sum_{i=1}^{m} \Sigma_{j=1}^{n} x_{i j}^{2}}}
$$

Step 2 Build the weight normalized matrix

$$
v_{i j}=w_{i} r_{i j}, i=1, \ldots m \quad j=1, \ldots, n
$$

Step 3 Calculate the positive and negative ideal solutions

$$
\begin{aligned}
& A^{+}=\left\{v_{1}^{+}, \ldots, v_{n}^{+}\right\} \text {, where } v_{j}^{+}=\left\{\max \left(v_{i j}\right) \in J ; \min \left(v_{i j}\right) \text { if } j \in J^{\prime}\right\} \\
& A^{-}=\left\{v_{1}^{-}, \ldots, v_{n}^{-}\right\}, \text {where } v_{j}^{*}=\left\{\min \left(v_{i j}\right) \in J ; \max \left(v_{i j}\right) \text { if } j \in J^{\prime}\right\}
\end{aligned}
$$

Step 4 Measure separation (positive and negative) measures for each alternative.

$$
\begin{gathered}
S_{i}^{+}=\sqrt{\sum_{j=1}^{n}\left(v_{j}^{+}-v_{i j}\right)^{2}}, \\
S_{i}^{-}=\sqrt{\sum_{j=1}^{n}\left(v_{j}^{-}-v_{i j}\right)^{2}, i=1, \ldots, m}
\end{gathered}
$$

Step 5 Finalize the relative closeness to the ideal solution.

$$
C_{i}^{+}=\frac{s_{i}^{-}}{\left(s_{i}^{-}+s_{i}^{+}\right)}, 0<C_{i}^{+}<1, i=1, \ldots m
$$

In the part of alternatives evaluation will apply by using the technique for order preference by similarity to ideal solution.

\subsection{Research Methodology}

The research purpose is to help project manager prioritize project by combining three methods including Expert interviews, the Analytic Hierarchy Process (AHP) and the technique for order preference by similarity to ideal solution (TOPSIS) in group decision making. The framework of research is shown as figure 1:

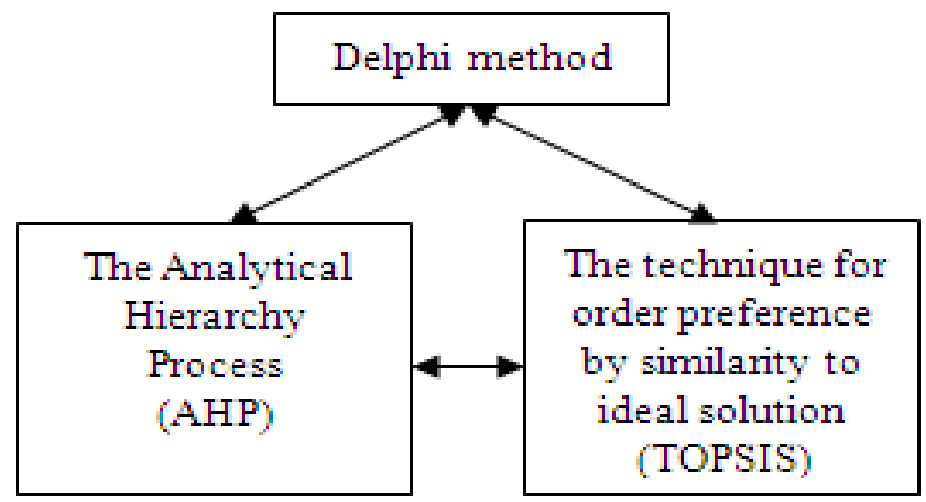

Figure 1. Research framework 
This section describes the detailed methodology which includes five steps to achieve research objective as the following;

Step1: Create questionnaire to get data from expert persons who are working in construction companies.

Step2: Determine criteria to prioritize project and determine project candidates.

Step 3: Construct decision hierarchy based on multi criteria method.

Step 4: Assign weight of each criterion with analytic hierarchy process then the result to prioritize the best project and assign weight of each candidate project by the technique for order preference by similarity to ideal solution.

Step 5 Evaluate alternatives and determine final ranking to prioritized projects.

The methodology of research is shown as figure 2;

\section{Delphi method}

-Created questionnaire to get data from expert.

-Detemine criteria and project candidate

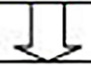

2.The Analytical Hierarchy Process(AHP)

-Created structure of decision

-Assigned weight of criteria

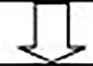

3. The technique for order preference by similarity to ideal solution (TOPSIS)

- Evaluated altematives and determine final rank to prioritized and selected project

Figure 2. Research methodology

Table 4. Pairwise score of criteria

\begin{tabular}{|c|c|c|c|c|c|}
\hline & $\begin{array}{c}\text { Man } \\
\text { power }\end{array}$ & $\begin{array}{c}\text { capit } \\
\text { al }\end{array}$ & $\begin{array}{c}\text { responsi } \\
\text { bility }\end{array}$ & $\begin{array}{c}\text { experien } \\
\text { ce of } \\
\text { worker }\end{array}$ & $\begin{array}{c}\text { machine } \\
\text { and } \\
\text { equipmen } \\
\text { t }\end{array}$ \\
\hline $\begin{array}{c}\text { Man } \\
\text { power }\end{array}$ & 1 & 1 & 4 & 4 & 3 \\
\hline capital & 1 & 1 & 5 & 5 & 3 \\
\hline $\begin{array}{c}\text { responsibilit } \\
\text { y }\end{array}$ & $1 / 5$ & $1 / 5$ & 1 & $1 / 5$ & $1 / 4$ \\
\hline $\begin{array}{c}\text { experience } \\
\text { of worker }\end{array}$ & $1 / 4$ & $1 / 5$ & 5 & 1 & 1 \\
\hline $\begin{array}{c}\text { machine } \\
\text { and } \\
\text { equipment }\end{array}$ & $1 / 3$ & $1 / 3$ & 4 & & 1 \\
\hline
\end{tabular}

\subsection{Results}

\subsubsection{Identification of Criteria}

This research study establishes and demonstrates the flow of the MCDM methodology, in which a case study in a construction company is given. The criteria are selected from expert persons who have worked in construction companies such as civil manager, maintenance, welding and mechanical, etc. by using expert interview method. Based on the results, criteria that will be used in the project selection of construction company consisting of five criteria used for evaluating the projects: manpower (C1), capital (C2), responsibility (C3), experience of worker (C4) and machine and equipment (C5) and seven projects are also selected in case study. After that, create structures and evaluate weights of criteria by means of The Analytic Hierarchy Process (AHP) as figure 3;

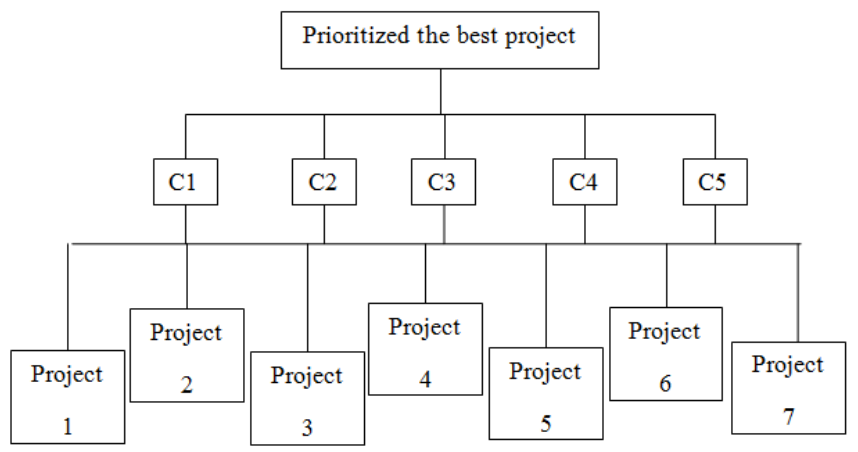

Figure 3. the decision hierarchy of project selection

\subsubsection{The Weights of Criteria}

In this step, the weights of the criteria used in evaluation process are calculated by using AHP method are presented in table 4 and rating score by the expert's team. The result weights of criteria are presented in table 5 .

Table 5. the weights of criteria by AHP method

\begin{tabular}{|c|c|c|c|c|c|}
\hline Criteria & Weight & $\lambda_{\max }$ & $\mathrm{CI}$ & $\mathrm{RI}$ & $\mathrm{CR}$ \\
\hline $\mathrm{C} 1$ & 0.331 & 5.251 & 0.0627 & 1.12 & 0.06 \\
\hline $\mathrm{C} 2$ & 0.360 & & & & \\
\hline $\mathrm{C} 3$ & 0.049 & & & & \\
\hline $\mathrm{C} 4$ & 0.127 & & & & \\
\hline $\mathrm{C} 5$ & 0.133 & & & & \\
\hline
\end{tabular}

Consistency ratio of the pair wise comparison matrix is calculated as $0.06<0.1$. So the weights are shown to be consistent and they are used in the selection process.

\subsubsection{Evaluation of Alternatives And Determine the Final Rank}

At the final step, the weight evaluation of alternatives had applied the technique for order preference by similarity to ideal solution (TOPSIS) for decision making. The result are summarizes in table 6 
Table 6. the ranking of project by TOPSIS method

\begin{tabular}{|c|c|c|}
\hline Project & Weight & Rank \\
\hline Project 1 & 0.358 & 6 \\
\hline Project 2 & 0.441 & 4 \\
\hline Project 3 & 0.614 & 3 \\
\hline Project 4 & 0.386 & 5 \\
\hline Project 5 & 0.747 & 1 \\
\hline Project 6 & 0.264 & 7 \\
\hline Project 7 & 0.746 & 2 \\
\hline
\end{tabular}

Therefore, the final ranking by TOPSIS is: project 5> project $7>$ project $3>$ project $2>$ project $4>$ project $1>$ project 6.

\section{Conclusions}

In this research paper, Expert interviews, AHP integrated TOPSIS methods are introduced to be used in project selection problem. Expert interviews are used to gather up and create criteria which mainly impacts to project, AHP is used to determine the weights of the decision criteria and TOPSIS is used to rank the alternatives. According to the result, all of methods provide the systematic approach for group decision making that can help project manager prioritize project and this information can help them provide master plan in project management and can be applied in other companies which tend to decide for project selection problem.

\section{Acknowledgements}

This research was work conducted while working at the faculty of Industrial Technology, Valaya Alonkorn Rajabhat University under the Royal Patronage. The researcher would like to express appreciation to Valaya Alonkorn Rajabhat University under the Royal Patronage for financial support.

\section{REFERENCE}

[1] A. A. a. S. S. Chauhan, "A hybrid approach integrating Affinity Diagram, AHP and fuzzy TOPSIS for sustainable city logistics planning," Applied Mathematical Modelling, vol. 36 , pp. 573-584, 2012.

[2] F. C.-G. Pablo Aragonés-Beltrán, Juan-Pascual Pastor-Ferrando and Andrea Pla-Rubio, "An AHP (Analytic Hierarchy Process)/ANP (Analytic Network Process)-based multi-criteria decision approach for the selection of solar-thermal power plant investment projects," Energy, vol. 66, pp. 222-238, 2014.
[3] N. M. a. M. J. H. Jahromib, "Propose a model to choose best project by AHP in distributed generation," Procedia Technology, vol. 1, pp. 481-484, 2012.

[4] A. T. a. T. A. Nooshin Rahmania, "Developing a Multi Criteria Model for Stochastic IT Portfolio Selection by AHP Method," Procedia - Social and Behavioral Sciences, vol. 62, pp. $1041-1045,2012$.

[5] M. I. A. Khalil, "Selecting the appropriate project delivery method using AHP," International Journal of Project Management, vol. 20, pp. 469-474, 2012.

[6] M. P. Amiri, "Project selection for oil-fields development by using the AHP and fuzzy TOPSIS methods," Expert Systems with Applications, vol. 37, pp. 6218-6224, 2010.

[7] F. A.-O. a. M. H. Doraid Dalalah, "Application of the Analytic Hierarchy Process (AHP) in Multi-Criteria Analysis of the Selection of Cranes," Jordan Journal of Mechanical and Industrial Engineering, vol. 4, pp. 567-578, 2010.

[8] C.-F. C. Chun-Chin Wei, Mao-Jiun J. Wang, "An AHP-based approach to ERP system selection," International Journal Production Economics, pp. 47-62, 2005.

[9] N. A. a. P. A. Laplante, "Software Project Management Tools: Making a Practical Decision Using AHP," Proceedings of the 30th Annual IEEE/NASA Software Engineering Workshop, 2006.

[10] K. M. A.-S. Al-Harbi, "Application of the AHP in project management," International Journal of Project Management, vol. 19, pp. 19-27, 2001.

[11] T. V. E.K. Zavadskasn, Z.Turskis and J.S aparauskas, "Multi-criteria analysis of Projects'performance in construction," Archeives of civil and mechanical engineering, vol. 14, pp. 114-121, 2014.

[12] B. Oztaysi, "A decision model for information technology selection using AHP integrated TOPSIS-Grey: The case of content management systems," Knowledge-Based Systems, 2014.

[13] E. T. a. S. H. Mann, "Using the Analytic Hierachy Process for decision making in engineering applications:some challenges " International Journal of Industrial Engineering: Applications and Practice, vol. 2, pp. 35-44, 1995.

[14] K. K.-D. a. S. Sadi-Nezhadb, "A hybrid fuzzy multiple criteria group decision making approach for sustainable project selection," Applied Soft Computing, vol. 13, pp. 339-352, 2013.

[15] J. S. S. Mahmoodzadeh, M. Pariazar, and M. S. Zaeri, "Project Selection by Using Fuzzy AHP and TOPSIS Technique," International Journal of Social, Human Science and Engineering, vol. 6, 2007.

[16] P. V. Amol A. Talankar, Nitin Seth, "Identification of Critical Success Factors in Non-Formal Service Sector Using Delphi Technique," International Journal of Social, Human Science and Engineering, vol. 8, 2014.

[17] N. G. a. B. Z. Othoman Elsayah, "Ranking of the Main Criteria for Contractor Selection Procedures on Major Construction Projects in Libya Using the Delphi Method," International Journal of Mechanical, Industrial Science and Engineering, vol. 7, 2013.

[18] D.-S. H. Han-Gook Kim, "Assessment of Green and Smart IT 
Level: A Case Study on Public Research Institute," World Academy of Science, Engineering and Technology, vol. 6, 2012.

[19] T. L. Saaty, "Decision making with the analytic hierarchy process," International Journal Services Sciences, vol. 1, 2008.

[20] A. R. a. S. A. Amir Mehdiabadi, "Ranking industries using a hybrid of DEA-TOPSIS," Decision Science Letters, vol. 2, pp. 251-256, 2013. 